\title{
Mera Vejetasyon Özelliklerinin Farklı Yöneylere Göre Değişimi*
}

\author{
Halit TUTAR ** Kağan KÖKTEN \\ Bingöl Üniversitesi, Ziraat Fakültesi, Tarla Bitkileri Bölümü, Bingöl, TÜRKİYE
}

\begin{tabular}{|c|c|}
\hline Geliş Tarihi/Received: 02.09 .2019 & Kabul Tarihi/Accepted: 08.11 .2019 \\
\hline ORCID ID (Yazar sirasina göre / by author order) & \\
\hline (DD) orcid.org/0000-0002-9341-3503 (D)orcid.org/0000-0001-5403-5629 & \\
\hline
\end{tabular}

Öz: Bu araştırma, Türkiye'nin Doğu Anadolu Bölgesi'nde yer alan Bingöl ili, Merkez ilçesi, Ormanardı Köyü’nde bulunan doğal bir meranın dört değişik yöneyinin verim ve kalite bakımından karşılaştırılması amacıyla yapılmıştır. Çalışmada; ağırlığa göre botanik kompozisyon, kuru ot verimi, otlatma kapasitesi, ham protein (HP) oranı ve verimi, asit deterjanda çözünmeyen lif (ADF) oranı, nötral deterjanda çözünmeyen lif (NDF) oranı, kuru madde tüketimi (KMT), sindirilebilir kuru madde tüketimi (SKM) ve nispi yem değeri (NYD) özellikleri incelenmiștir. Araștırmada, ağırlığa göre botanik kompozisyonun \% 67.5'ini buğdaygiller, \% 32.5'ini diğer familyalara ait bitkiler oluştururken, botanik kompozisyon içinde baklagil bitkisinin olmadığı tespit edilmiștir. Calıșmada kuru ot veriminin, mera yöneylerine göre 23.2-129.3 kg da-1 arasında değiştiği ve mera yöneylerinin kuru ot verimi değerleri açısından istatistiksel olarak önemli olduğu saptanmıştır $(\mathrm{p}<0.01$ ). Meranın otlatma kapasitesi $18.4 \mathrm{HB}$ (Hayvan birimi) olarak hesaplanmıștır. Araștırma sonucunda, HP verimi ve HP oranı, ADF, NDF, KMT, SKM ve NYD sirasiyla; 2.3-16.7, \% 9.9-12.9, \% 34.8-37.4, \% 52.5-62.7, \% 1.92-2.08, \% 59.761.7 ve 91.8-109.4 arasında olduğu tespit edilmiştir.

Anahtar Kelimeler: Mera, otlatma kapasitesi, ot verimi, ham protein oranı, nispi yem değeri

\section{Variation of Rangeland Vegetation Characteristics According to Different Aspects}

\begin{abstract}
This research was conducted to compare four different aspects of a natural rangeland in Ormanardı Village of Central district in Bingöl province, South East Anatolia for hay yield and quality. In this study; botanical composition by weight, hay yield, grazing capacity, crude protein (CP) ratio and yield, acid detergent insoluble fiber (ADF) ratio, neutral detergent insoluble fiber (NDF) ratio, dry matter consumption (DMC), digestible dry matter consumption (DDMC) and relative feed value (RFV) properties were investigated. According to the research, $67.5 \%$ of the botanical composition is composed of poaceous plants and $32.5 \%$ of the plants belonged to other families, while it is determined that there are no legume plants in the botanical composition. In the study, it was found that hay yield ranged between $23.2-129.3 \mathrm{~kg} \mathrm{da}^{-1}$ according to rangeland aspects, and it was statistically significant in terms of hay yield values of rangeland aspects $(\mathrm{p}<0.01)$. Grazing capacity of the rangeland was calculated as $18.4 \mathrm{HB}$. Percent contributions of grasses and other family plants in the hay yield were $67.5 \%$ and $32.5 \%$, respectively. As a results of research, CP yield and ratio, ADF, NDF, DMC, DDMC and RFV contents ranged between 2.3 to $16.7 \mathrm{~kg} \mathrm{da}^{-1}, 9.9$ to $16.7 \%, 34.8$ to $37.4 \%, 52.5$ to $62.7 \%, 1.92$ to $2.08 \%, 59.7$ to $61.7 \%$ and between 91.8 to 109.4 , respectively.
\end{abstract}

Keywords: Pasture, grazing capacity, herbage yield, crude protein ratio, relative feed value

\section{Giriş}

Çayır-mera alanları, bir ülkenin sahip olduğu en önemli doğal zenginliklerden birisi olmakla beraber hayvansal üretimde en önemli girdi olan kaba yemi oluşturması açısından da büyük bir paya sahiptir. Türkiye'de hayvanların ihtiyaç duydukları

\footnotetext{
": Bu çalışma; Bingöl Üniversitesi, Fen Bilimleri Enstitüsü tarafından kabul edilen birinci yazara ait "Bingöl İli Merkez İlçesi Ormanardı Köyü Merasının Verim ve Botanik Kompozisyonunun Saptanması” isimli Yüksek Lisans Tez çalıșmasının bir bölümünden üretilmiș olup; 03-06 Mayıs 2018 tarihlerinde Moldova'da düzenlenen Uluslararası Tarım Kongresi'nde sözlü bildiri olarak sunulmuş ve adı geçen kongre bildiriler kitabında özet metni yayınlanmıştır.
} 
kaba yemlerin 1/3'ü çayır-mera alanlarından karşılanmaktadır (Gökkuş, 1994).

Türkiye'de mera varlığı 20. yüzyılın ortasından itibaren giderek azalma eğilimi göstermiş ve yüzyılın başlarında 44 milyon hektar olan mera arazisi varlığ1 günümüzde 14.6 milyon hektara kadar düşmüştür. Türkiye'de Doğu Anadolu Bölgesi, toplam mera alanının \% 37.5'ine sahip olup; bu bölge sınırları içerisinde yer alan Bingöl ilinde meralar, 414.407 hektar alanı kaplamaktadır (Anonim, 2019).

Ülke ve tarım ekonomisi için büyük bir öneme sahip olan doğal mera alanları aynı zamanda, sürdürülebilir ve doğal bir denge için de çok önemlidir. Meraların yanlış ve bilinçsiz kullanımının yanında; çevre faktörleri, anormal iklim koşulları ve diğer sosyo-ekonomik etkenler verimliliğe önemli ölçüde zarar vermektedir (Altın ve ark., 2011).

Türkiye meraları, otlatma kapasitelerinin yaklaşık 2-3 katı üzerinde hayvanla otlatılmalarının sonucunda verimliliklerini önemli ölçüde yitirmiş durumdadır (Koç ve Gökkuş, 1994). Türkiye'de meraların tahmini ortalama ot verimi $70 \mathrm{~kg} \mathrm{da} \mathrm{da}^{-1}$ olup, dünya ortalamasının yaklaşık 1/3'ü seviyesindedir (Babalık, 2008).

Çayır-meralarda vejetasyon inceleme ve ölçümlerinin iki ana hedefi vardır. Birincisi vejetasyonu iyi bilinmeyen bölgelerdeki çayır ve mera alanlarının kalitatif ve kantitatif özellikleri hakkında bilgiler edinmektir. İkincisi ise çayır ve meralarda uygulanacak islah ve amenajman yöntemleri ile bunların bitki örtüsü üzerindeki etkilerini incelemektir (Cerit ve Altın, 1999).

$\mathrm{Bu}$ çalışmada; Türkiye'nin Doğu Anadolu Bölgesi'nde yer alan bir meranın yöneyler itibariyle verim ve kalite açısından incelenerek, benzer ekolojik bölgelerdeki meraların ıslahında temel teşkil edecek bilgilerin elde edilmesi amaçlanmıştır.

\section{Materyal ve Yöntem}

Çalışma, Türkiye'nin Doğu Anadolu Bölgesi'nde yer alan Bingöl ili Merkez ilçeye bağlı Ormanardı köyünde bulunan 551 dekar büyüklüğünde bir merada, 2017 yılının Mayıs-Haziran aylarında yürütülmüştür. Çalışma yerinin deniz seviyesinden yüksekliği 1100-1180 m arasında değişmektedir.

Bingöl iline ait uzun y1llar (1975-2017) ve araştırma yılına ait bazı iklim verileri Tablo 1'de verilmiștir. Tablo 1'den de anlaşılacağ 1 üzere, Bingöl'de uzun yıllar verilerine göre; sıcaklık ortalamas $11.5^{\circ} \mathrm{C}$, en soğuk aylar Ocak ve Şubat, en sıcak aylar ise Temmuz ve Ağustos olmuştur. Araştırma yılında ise yıllık ortalama sıcaklık derecesi $12.8{ }^{\circ} \mathrm{C}$ olarak gerçekleşmiş, Aralık ve Ocak en soğuk aylar iken, Temmuz ve Ağustos ayları uzun yıllar verilerinde olduğu gibi en sıcak aylar olarak kayda geçmiştir. Genel olarak, araştırmanın yürütüldüğü yılın, uzun yıllara göre daha sıcak ve yağış miktarının daha düşük olduğu söylenebilir (Tablo 1).

Tablo 1. Bingöl iline ait uzun yıllar (1975-2017) ve araştırma yılı (2017) yılı bazı iklim verileri (Anonim, 2017)

\begin{tabular}{|c|c|c|c|c|c|c|}
\hline \multirow{2}{*}{ Aylar } & \multicolumn{2}{|c|}{ Ortalama sicaklık $\left({ }^{\circ} \mathrm{C}\right)$} & \multicolumn{2}{|c|}{ Nispi nem (\%) } & \multicolumn{2}{|c|}{ Toplam yağış (mm) } \\
\hline & Uzun yillar & 2017 & Uzun yillar & 2017 & Uzun yillar & 2017 \\
\hline Ocak & -2.6 & -2.8 & 72.2 & 75.3 & 121.6 & 235.1 \\
\hline Şubat & -1.6 & 2.4 & 71.5 & 73.7 & 144.7 & 86.3 \\
\hline Mart & 3.6 & 7.0 & 66.9 & 60.4 & 130.2 & 125.5 \\
\hline Nisan & 10.2 & 14.0 & 59.2 & 48.4 & 120.8 & 45.5 \\
\hline Mayıs & 17.4 & 16.3 & 53.1 & 57.4 & 77.1 & 62.2 \\
\hline Haziran & 21.3 & 22.2 & 43.3 & 43.6 & 21.0 & 34.6 \\
\hline Temmuz & 25.0 & 27.0 & 35.1 & 33.4 & 8.4 & 3.5 \\
\hline Ağustos & 24.6 & 28.1 & 37.5 & 28.0 & 5.1 & 0.0 \\
\hline Eylül & 20.3 & 20.1 & 43.1 & 40.3 & 11.5 & 29.1 \\
\hline Ekim & 13.5 & 15.2 & 57.3 & 43.0 & 69.1 & 4.4 \\
\hline Kasım & 6.2 & 6.4 & 68.0 & 48.0 & 113.6 & 53.7 \\
\hline Aralık & 0.4 & -2.2 & 73.6 & 73.4 & 139.8 & 152.6 \\
\hline Ortalama/Toplam & 11.5 & 12.8 & 56.7 & 52.1 & 962.9 & 832.5 \\
\hline
\end{tabular}

Araştırmanın yapıldığı mera alanının eğimi \% 15-40 olup, VII. sınıf arazi özellikleri taşıdığ1 tespit edilmiştir. Çalışma sahasını kapsayan toprakların bazı fiziksel ve kimyasal özellikleri ise Tablo 2'de sunulmuştur. Tablo 2'de verilen toprak analiz sonuçlarına göre, incelenen mera topraklarının; tınlı tekstürlü, tuzsuz, hafif asit karakterli, organik madde ve kireç içeriğinin az, alınabilir fosfor ve potasyum kapsamlarının ise orta düzeyde olduğu tespit edilmiştir. 
Tablo 2. Araştırma alanı topraklarının bazı fiziksel ve kimyasal özellikleri $(0-30 \mathrm{~cm})$

\begin{tabular}{lc}
\hline Toprak özelliği & Değeri \\
\hline $\mathrm{pH}$ & 6.57 \\
Organik madde, \% & 1.91 \\
Kireç $\left(\mathrm{CaCO}_{3}\right), \%$ & 0.4 \\
Toplam tuz, \% & 0.032 \\
Alınabilir fosfor, $\mathrm{kg} \mathrm{P}_{2} \mathrm{O}_{5} \mathrm{da}^{-1}$ & 7.9 \\
Alınabilir potasyum, $\mathrm{kg} \mathrm{K}_{2} \mathrm{O} \mathrm{da}^{-1}$ & 25 \\
\hline
\end{tabular}

Deneme alanında mera vejetasyon ölçümleri; güney, kuzey, doğu, batı yöneyleri olmak üzere 4 farklı yöneyde, 31 Mayıs ve 01-02 Haziran 2017 tarihlerinde yapılmıştır. Çalışmaya konu olan yöneyler, yamaçların baktığı yön esas alınarak adlandırılmıştır.

Araştırma alanının vejetasyon ölçümlerinde, nokta quadrat yönteminin farklı bir versiyonu olan, yarı kurak ve kurak mera vejetasyonlarındaki değişimlerin kolay bir şekilde izlenmesini sağlayan, "lup" yöntemi kullanılmıştır (Anonim, 1962).

Meranın her yöneyinde vejetasyon, toprak ve eğim açısından üniform olan üç parsel belirlenmiş ve her bir parselde 20 m'lik 4 adet lup hattında ölçüm yapılmıştır. Lup hatları üzerinde her 20 cm'de bir, $2 \mathrm{~cm}$ çapında ve $30 \mathrm{~cm}$ boyunda olan lup düşey doğrultuda yere indirilerek lup içerisinde bulunan bitki türü kaydedilmiştir. Lup içerisine birden fazla tür girmiş ise sadece baskın durumda olan bitki türü değerlendirilmiştir (Cornellius ve Alınoğlu, 1962). Dolayısıyla her 20 m'lik lup hattı üzerinde toplam 100, her parselde 400, her yöneyde ise 1200 adet olmak üzere araştırma alanında toplam 4800 lup ölçümü yapılmıştır.

Çalışmada; Tosun ve Altın (1986) ve Aydın ve ark. (2014)'na göre ağırlığa göre botanik kompozisyon, Tosun ve Altın (1986) ve Uzun (2010)'a göre kuru ot verimi, ham protein (HP) oranı ve HP verimi değerleri tespit edilmiştir. Otlatma kapasitesi, Eşitlik 1 yardımıyla Erkun (1971), Yılmaz (1977) ve Tükel (1981) tarafindan bildirildiği şekilde belirlenmiştir.

$$
O . K .=(a * b * c) /(d * e)
$$

Eşitlikte O.K., otlatma kapasitesini; a, mera alanın1; b, mera verimini; c, faydalanılabilir yem oranını; d, bir hayvanın günlük yem tüketimini; e, otlatma gün sayısını ifade etmektedir. Çalışma alanının bulunduğu bölge yarı kurak bir yer olmasindan dolay1, faydalanılabilir yem oranı \% 50 olarak alınmıştır (Tükel ve Hatipoğlu, 1997). $\mathrm{Bu}$ sebeple, yukarıdaki formülde bir hayvanın günlük yem ihtiyacı, $500 \mathrm{~kg}$ canlı ağırlığındaki bir hayvanın canlı ağırlığının \% 2.5'i kadar kuru ot tüketebileceği dikkate alınarak günlük $12.5 \mathrm{~kg}$ olarak alınmıştır.
Bakır (1970) tarafindan bildirilen formüle göre de, 1 hayvan birimi (HB) için bir otlatma mevsiminde gerekli mera alanı Eşitlik 2 yardımıyla hesaplanmıştır.

$$
A=(x * y) /(z * t)
$$

Eşitlikte A, 1 HB için gerekli mera alanını (dekar); x, otlatma periyodunu (gün); y, 1 HB'nin 1 günlük kuru ot gereksinimini; $z$, mera verimini; $t$, faydalanılabilir yem oranını ifade etmektedir.

Araştırmada, nötral deterjanda çözünmeyen lif (NDF) oranı Van Soest ve Wine (1967)'a göre, asit deterjanda çözünmeyen lif (ADF) oranı ise Van Soest (1963)'e göre ANKOM 200 Fiber Analyzer (ANKOM Technology Corporation Fairport, NY, USA) cihazı kullanılarak analiz edilmiştir. ADF ve NDF analiz sonuçları kullanılarak Morrison (2003)'a göre Eşitlik 3-5 yardımıyla sindirilebilir kuru madde (SKM), kuru madde tüketimi (KMT) ve nispi yem değeri (NYD) hesaplanmıştır.

$$
\begin{aligned}
& \mathrm{SKM}=88.9-(0.779 \times \% \text { ADF }) \\
& \mathrm{KMT}=120 /(\% \mathrm{NDF}) \\
& \mathrm{NYD}=(\mathrm{SKM} \times \mathrm{KMT}) / 1.29
\end{aligned}
$$

Analiz ve değerlendirme yöntemleri, SAS istatistik paket programı yardımıyla analizi uygulamış ve ortalamalar arasındaki farklılıklar LSD testi ile karşılaştırılmıştır (Anonymous, 1999).

\section{Bulgular ve Tartışma}

\subsection{Ağırlığa göre botanik kompozisyon}

Meranın her bir yöneyinde tespit edilen ağırlığa göre botanik kompozisyonda buğdaygillerin ve diğer familya bitkileri oranları Tablo 3 'te verilmiş olup, baklagiller oranı ise tespit edilememiştir. Ağırlığa göre botanik kompozisyonda buğdaygiller ve diğer familya bitkileri açısından yöneyler arasındaki farkların istatiksel olarak $\% \quad 1$ seviyesinde önemli olduğu tespit edilmiştir. Ağırlığa göre botanik kompozisyonda buğdaygiller \% 80.8 ile en fazla güney yöneyinde elde edilirken, bunu istatistiki olarak aynı grupta yer alan batı (\% 68.2) yöneyi takip etmiştir. En düşük buğdaygil oranı ise doğu (\% 58.8) yöneyinde tespit edilmiştir. Ağırlığa göre botanik kompozisyonda buğdaygillerin oranı ortalama \% 67.5 olarak bulunmuştur (Tablo 3). Ağırlığa göre botanik kompozisyonda buğdaygil oranı ile ilgili elde edilen bu değerler Türkiye'nin farklı ekolojilerinde yürütülen bazı araştırma bulgularından (Nadir, 2010; Ağın, 2012; Aydın, 2014; Çaçan ve Başbağ, 2016; Seydoşoğlu, 2018; Seydoşoğlu ve Kökten, 2019) yüksek iken, Taşdemir (2015)'in elde ettiği değerden düşük, Şen (2010)'in elde ettiği değer ile 
benzerlik göstermiştir. Mera alanındaki buğdaygil oranının farklı olması; mera vejetasyon yöntemlerinin, mera alanının büyüklüğünün ve özellikle ekolojik koşulların farklı olması ile açıklanabilir.

Tablo 3. Mera yöneylerine göre ağırlığa göre botanik kompozisyonda buğdaygillerin ve diğer familya bitkilerinin oranı $(\%)^{1}$

\begin{tabular}{lcc}
\hline Yöneyler & Buğdaygiller & $\begin{array}{c}\text { Diğer familya } \\
\text { bitkileri }\end{array}$ \\
\hline Güney & $80.8 \mathrm{a}$ & $19.2 \mathrm{~b}$ \\
Kuzey & $62.2 \mathrm{~b}$ & $37.8 \mathrm{a}$ \\
Bat1 & $68.2 \mathrm{ab}$ & $31.8 \mathrm{ab}$ \\
Doğu & $58.8 \mathrm{~b}$ & $41.2 \mathrm{a}$ \\
\hline Ortalama & 67.5 & 32.5 \\
\hline LSD & $10.155^{* *}$ & $9.984^{* *}$ \\
\hline
\end{tabular}

: Aynı sütunda aynı harfle gösterilen ortalamalar arasındaki farkl1l1k önemli değildir, ${ }^{* * *}: \mathrm{p}<0.01$ düzeyinde önemli farkl1l1k

A ğırlığa göre botanik kompozisyonda diğer familya bitkileri oranı en fazla \% 41.2 ile doğu yöneyinde elde edilirken, bunu istatistiki açıdan aralarındaki farklılığın önemsiz olduğu kuzey (\% 37.8) ve batı (\% 31.8) yöneyleri takip etmiștir. En düşük diğer familya bitkileri oranı ise \% 19.2 ile güney yöneyinde tespit edilmiştir. Ağırlığa göre botanik kompozisyonda diğer familya bitkileri ortalaması \% 32.5 olarak bulunmuştur (Tablo 3). Ağırlığa göre botanik kompozisyonda diğer familya bitkileri oranı ile ilgili elde edilen bu değerler Aydın (2014) ve Taşdemir (2015)'in elde ettikleri değerlerden yüksek iken, Ağın (2012) ve Çaçan ve Başbağ (2016)'ın elde ettiği değerlerden düşük; Nadir (2010), Şen (2010) ve Seydoşoğlu ve ark. (2019)'nın elde ettiği değerler ile uyum göstermektedir. Ağırlığa göre botanik kompozisyondaki diğer familya bitkilerinin farklı olması, buğdaygillerde olduğu gibi mera alanının büyüklüğü, iklim faktörleri ve mera vejetasyon ölçümünün farklı olmasından kaynaklandığ söylenebilir.

\subsection{Kuru ot verimi}

Çalışmanın yapıldığı mera yöneylerinde saptanan kuru ot verimleri Tablo 4'te verilmiştir. Kuru ot verimleri açısından yöneyler arasındaki farkların istatiksel olarak \% 1 seviyesinde önemli olduğu tespit edilmiştir (Tablo 4).

Meranın kuru ot verimi yöneylere göre ortalama $87.7 \mathrm{~kg} \mathrm{da}^{-1}$ olarak bulunmuştur. En fazla kuru ot verimi $129.3 \mathrm{~kg} \mathrm{da}^{-1}$ ile güney yöneyinden elde edilirken, bunu istatistiki açıdan aralarındaki farklılığın önemsiz olduğu doğu $\left(100.6 \mathrm{~kg} \mathrm{da}^{-1}\right)$ yöneyi izlemiştir. En düşük kuru ot verimi ise 23.2 $\mathrm{kg} \mathrm{da}{ }^{-1}$ ile kuzey yöneyinden tespit edilmiştir (Tablo 4). Kuru ot verimi ile ilgili elde edilen değerler Bilgin (2010), Nadir (2010), Şahinoğlu
(2010), Ağın (2012), Aydın (2014), Taşdemir (2015), Çaçan ve Başbağ (2016)'ın elde ettikleri değerlerden düşük bulunurken, Buzuk ve ark. (2009)'nın elde ettiği değerden yüksek; Türker ve Tükel (2006), Babalık ve Sönmez (2010), Şen (2010) ve Seydoşoğlu ve ark. (2019)'nın elde ettiği değerlerler ile uyum göstermektedir. Kuru ot veriminin farklı olması, özellikle mera alanının ekolojik koşullarından kaynaklandığı söylenebilir.

Tablo 4. Mera yöneylerine ait kuru ot verimi, HP oranı ve HP verimi ${ }^{1}$

\begin{tabular}{lccc}
\hline Yöneyler & $\begin{array}{c}\text { Kuru ot } \\
\text { verimi } \\
\left(\mathrm{kg} \mathrm{da}^{-1}\right)\end{array}$ & $\begin{array}{c}\mathrm{HP} \\
\text { oran } 1 \\
(\%)\end{array}$ & $\begin{array}{c}\mathrm{HP} \\
\text { verimi } \\
\left(\mathrm{kg} \mathrm{da}^{-1}\right)\end{array}$ \\
\hline Güney & $129.3 \mathrm{a}$ & $12.9 \mathrm{a}$ & $16.7 \mathrm{a}$ \\
Kuzey & $23.2 \mathrm{c}$ & $9.9 \mathrm{~b}$ & $2.3 \mathrm{c}$ \\
Bat1 & $95.4 \mathrm{~b}$ & $11.6 \mathrm{a}$ & $11.1 \mathrm{~b}$ \\
Doğu & $100.6 \mathrm{ab}$ & $11.2 \mathrm{ab}$ & $11.4 \mathrm{~b}$ \\
\hline Ortalama & 87.7 & 11.4 & 10.4 \\
\hline LSD & $33.622^{* *}$ & $1.717^{*}$ & $5.184^{* *}$ \\
\hline
\end{tabular}

${ }^{1}$ : Aynı sütunda aynı harfle gösterilen ortalamalar arasındaki farklı1ık önemli değildir, ${ }^{*}: \mathrm{p}<0.05$ düzeyinde önemli farkl111k, ${ }^{* *}: \mathrm{p}<0.01$ düzeyinde önemli farkl111k

\subsection{Otlatma kapasitesi}

Otlatma kapasitesi; uzun yıllar bitki örtüsü, toprak ve diğer doğal kaynaklara tahrip etmeden birim alanda otlatılabilecek maksimum hayvan sayısıdır (Gökkuş ve ark., 1993). Bingöl ilinde 105 günlük (15 Mayıs-01 Eylül) bir otlatma mevsiminde, araştırmada incelenen 551 dekarlık meranın ortalama kuru ot verimi $87.7 \mathrm{~kg} \mathrm{da}{ }^{-1}$ (Tablo 4) olup, hayvan birimi (HB) olarak otlatma kapasitesi aşağıdaki gibi hesaplanmıştır.

$$
\text { O.K. }=(551 * 87.7 * 0.5) /(12.5 * 105)=18.4 \mathrm{HB}
$$

Ormanardı köyünde mevcut HB sayıs1 92'dir. Çalışma alanı, 18.4 HB'nin ihtiyacını karşılayamayacak durumdadır. Bir hayvanın günlük tükettiği kuru ot miktarı ve otlatma süresi baz alınarak, bir otlatma periyodunda bir hayvana gerekli olan mera alanı ise;

$1 \mathrm{HB}$ için gerekli mera alanı $=(105 * 12.5) /$ $(87.7 * 0.5)=29.9$ dekardir.

1 hayvan birimine 29.9 da mera alanı gerektiği görülmektedir. Elde edilen sonuçlar, Gökkuş ve ark. (1993), Çınar (2001) ve Taşdemir (2015)'in elde ettikleri sonuçlardan yüksek bulunmuştur. Yüksek olmasının nedeni olarak, mera alanında otlatılan hayvan sayısının farklı olmasindan kaynaklandığı söylenebilir.

\subsection{Ham protein oranı ve ham protein verimi}

Çalışmanın yapıldığı meranın her bir yöneyinde elde edilen HP oranları ve verimleri Tablo 4'te verilmiştir. Ham protein oranı değerleri yöneyler açısından istatistiki olarak \% 5 seviyesinde önemli 
olduğu, HP verimi değerleri yöneyler açısından ise \% 1 seviyesinde önemli olduğu anlaşılmaktadır (Tablo 4).

Çalışma alanında HP oranı ortalama olarak \% 11.4 saptanmıştır. En fazla HP oranı istatistiki olarak aynı grupta yer alan güney $(\% 12.9)$ ve batı (\% 11.6) yöneylerinden elde edilirken, bunu istatistiki açıdan aralarındaki farklılığın önemsiz olduğu doğu (\% 11.2) yöneyi takip etmiștir. En düşük HP oranı ise \% 9.9 ile kuzey yönünde saptanmıştır (Tablo 4). Elde edilen HP oranları yönünden, birçok araştırıcının yaptığ 1 çalışmalarıyla benzerlikler ve farklılıklar olduğu tespit edilmiştir (Çınar, 2001; Erkovan ve ark., 2009; Nadir, 2010; Şahinoğlu, 2010, Budaklı Çarpıcı, 2011; Aydın, 2014; Çaçan, 2014; Taşdemir, 2015). Ham protein oranının farklılı̆̆ botanik kompozisyondaki baklagil oranının farklılığından kaynaklanmaktadır.

Çalışılan meranın HP verimi ise ortalama olarak $10.4 \mathrm{~kg} \mathrm{da}^{-1}$ bulunmuştur. En fazla HP verimi $16.7 \mathrm{~kg} \mathrm{da}^{-1}$ ile güney yöneyinde, en düşük HP verimi ise kuzey $\left(2.3 \mathrm{~kg} \mathrm{da}^{-1}\right)$ yöneyinde tespit edilmiştir (Tablo 4). Protein verimi ile ilgili elde edilen değerler; birçok araştırmacıların (Çınar, 2001; Nadir, 2010; Şahinoğlu, 2010; Şen, 2010; Ağın, 2012; Çaçan, 2014; Taşdemir, 2015) elde ettiği değerlerden düşük bulunmuştur. Bunun nedeni olarak, HP oranında olduğu gibi botanik kompozisyondaki bitki türlerinin farklı olmasından kaynaklanmaktadır.

\subsection{Mera kuru otunun ADF, NDF, SKM ve KMT oranları ile nispi yem değeri}

Çalışmanın yapıldığı mera yöneylerinde elde edilen kuru otun ADF, NDF, KMT, SKM oranları ve NYD Tablo 5'te verilmiştir. Ad1 geçen bu özellikler yönünden yöneyler arasındaki farklılık istatistiki olarak önemsiz bulunmuştur.

Tablo 5. Mera yöneylerine göre kuru otun ADF, NDF, SKM ve KMT oranları ile nispi yem değerleri

\begin{tabular}{lccccc}
\hline Yöneyler & $\begin{array}{c}\text { ADF } \\
(\%)\end{array}$ & $\begin{array}{c}\text { NDF } \\
(\%)\end{array}$ & $\begin{array}{c}\text { SKM } \\
(\%)\end{array}$ & $\begin{array}{c}\text { KMT } \\
(\%)\end{array}$ & NYD \\
\hline Güney & 34.8 & 62.7 & 61.7 & 1.92 & 91.8 \\
Kuzey & 35.2 & 60.8 & 61.4 & 1.98 & 94.3 \\
Bat1 & 37.4 & 56.0 & 59.7 & 2.14 & 99.4 \\
Doğu & 34.8 & 52.5 & 61.7 & 2.28 & 109.4 \\
\hline Ortalama & 35.6 & 58.0 & 61.1 & 2.08 & 98.7 \\
\hline LSD & 5.29 & 13.19 & 4.12 & 0.44 & 18.82 \\
\hline
\end{tabular}

Araştırma yapılan meradaki kuru otun ADF oranı yöneylere göre \% $34.8-37.4$ arasında değiştiği belirlenmiştir (Tablo 5). ADF oranı ile ilgili elde edilen bu değerler; Erkovan ve ark. (2009), Nadir (2010), Şahinoğlu (2010) ve Aydın (2014)'ın elde ettikleri değerlerden düşük iken;
Güllap (2010), Budaklı Çarpıcı (2011), Çaçan (2014) ve Taşdemir (2015)'in elde ettikleri değerler ile benzerlik göstermektedir. ADF oranı yönünden literatürlerle olan farkl1lık, vejetasyonda yer alan baklagil ve buğdaygil bitkilerinin oranlarının farklı olması ile açıklanabilir.

Tablo 5'e bakıldığında, ölçüm yapılan mera yöneyleri bakımından mera kuru otunun NDF oranı \% 52.5 ile \% 62.7 arasında değiştiği tespit edilmiştir. Elde edilen değerler Erkovan ve ark. (2009), Güllap (2010), Nadir (2010), Şahinoğlu (2010), Budaklı Çarpıcı (2011), Aydın (2014), Çaçan (2014) ve Taşdemir (2015)'in elde ettikleri değerlerden yüksek tespit edilmiştir. $\mathrm{Bu}$ yüksekliğin nedeni olarak, mera alanında yer alan bitkilerin oranlarındaki farklılık olduğu söylenebilir.

Ölçüm yapılan merada SKM oranı ortalama olarak \% 61.1 olarak tespit edilmiş olup, SKM oranı \% 59.7-61.7 arasında değişiklik göstermiştir (Tablo 5). Elde edilen değerler Aydın (2014)'ın elde ettiği değerden düşük iken; Çaçan (2014) ve Taşdemir (2015)'in elde ettikleri değerler ile uyum içerisindedir. SKM değerinin düşük çıkması, mera alanında yer alana ADF ve NDF oranlarının farklı olmasından kaynaklanmaktadır.

Çalışma yapılan alanın KMT oranı ortalama olarak \% 2.08 olarak bulunmuş olup, KMT oranı \% 1.92-\% 2.28 arasında değişim göstermiştir (Tablo 5). Elde edilen değerler Aydın (2014), Çaçan (2014) ve Taşdemir (2015)'in elde ettiği değerlerden düşük olduğu tespit edilmiştir. Literatürlerle olan bu farklılık, SKM oranında olduğu gibi, mera otunun ADF ve NDF oranlarının değişikliğinden kaynaklanması ile açıklanabilir.

Tablo 5 incelendiğinde, araştırma yapılan mera alanından elde edilen kuru otların nispi yem değerleri 91.8 ile 109.4 arasında değişim gösterdiği tespit edilmiştir. NYD ile ilgili elde edilen bu değerler; Nadir (2010), Aydın (2014), Çaçan (2014) ve Taşdemir (2015)'in buldukları değerlerden düşük iken, Şahinoğlu (2010)'nun bulduğu değerden yüksek olduğu tespit edilmiştir.

\section{Sonuçlar}

Ormanardı köyü merası kuru ot verimi, otlatma kapasitesi, ham protein oranı ve ham protein verimi açısından zayıf olduğu tespit edilmiștir. Bunun sebebi vejetasyondaki bitki türlerindeki farklı1ıktan kaynaklanmaktadır.

Mera çalışması neticesinde elde edilen NDF, ADF, KMT, SKM oranları ve NYD değerlerinin çalışılan yöneyler açısından istatistiksel olarak bir farklılık göstermediği tespit edilmiştir. $\mathrm{Bu}$ parametreler açısından yöneyler arasında bir 
farklılık bulunmamasının nedeni tüm meranın birbirine benzer özellikte olmasından kaynaklanmaktadır.

Çalışma sonucunda elde edilen verilere göre; meranın 1slah edilmesi gerektiği sonucuna varılmıștır. Söz konusu meranın amenajman kurallarına uygun olarak otlatılması gerektiği ve gübreleme ile sslah edilmesi gerektiği kanısına varılmıştır.

\section{Kaynaklar}

Ağın, Ö., 2012. Bingöl ili Yedisu ilçesi Karapolat köyü merasının verim ve botanik kompozisyonunun saptanması. Yüksek lisans tezi, Bingöl Üniversitesi Fen Bilimleri Enstitüsü, Bingöl.

Altın, M., Gökkuş, A., Koç, A., 2011. Çayır Mera Yönetimi. I. Cilt (Genel İlkeler). T.C. Tarım ve Köyişleri Bakanlığı, Tarımsal Üretim ve Geliştirme Genel Müdürlüğü, Ankara.

Anonim, 1962. Range Research: Basic Problems and Techniques in Range Research. National Academy of Science, National Research Council Puplication.

Anonim, 2017. Bingöl İli İklim Verileri. Bingöl Meteroloji Müdürlüğü, Bingöl.

Anonim, 2019. Bitkisel Üretim İstatistikleri. Türkiye İstatistik Kurumu, (www.tuik.gov.tr), (Erişim tarihi: 25.07.2019).

Anonymous, 1999. SAS User's Guide: Statistic. Statistical Analysis Systems Institute Inc., Cary, NC.

Aydın, A., 2014. Karacadağ'ın farklı yükseltilerindeki meralarında bitki tür ve kompozisyonları ile ot verim ve kalitelerinin belirlenmesi. Doktora tezi, Dicle Üniversitesi Fen Bilimleri Enstitüsü, Diyarbakır.

Aydın, A., Çaçan, E., Başbağ, M., 2014. Mardin ili Derik ilçesinde yer alan bir meranın botanik kompozisyonunun belirlenmesi. Türk Tartm ve Doğa Bilimleri Dergisi, 2(Özel Say1s1): 1631-1637.

Babalık, AA., 2008. Isparta yöresi meralarının vejetasyon yapıs1 ile toprak özellikleri ve topoğrafik faktörler arasındaki ilişkiler. Doktora tezi, Süleyman Demirel Üniversitesi Fen Bilimleri Enstitüsü, Isparta.

Babalık, AA., Sönmez, K., 2010. Isparta İli Bozanönü Köyü kırtepe merasında botanik kompozisyonun belirlenmesi üzerine bir araștırma. Bartın Orman Fakültesi Dergisi, 12(17): 27-35.

Bakır, Ö., 1970. Orta Doğu Teknik Üniversitesi Arazisinde Bir Mera Etüdü. Ankara Üniversitesi Ziraat Fakültesi Yayınları No: 232, Ankara.

Bilgin, F., 2010. Artvin Ardanuç-Aydın Köyü yaylası mera vejetasyonu ile bazı toprak özelliklerinin yükseltiye göre değişiminin irdelenmesi. Yüksek lisans tezi, Artvin Çoruh Üniversitesi Fen Bilimleri Enstitüsü, Artvin.

Budaklı Çarpıc1, E., 2011. Changes in leaf area index, light interception, quality and dry matter yield of an abandoned rangeland as affected by the different levels of nitrojen and phosphorus fertilization. Turkish Journal of Field Crops, 16(2): 117-120.

Buzuk, G., Sabanc1, C.O., Ertuş, M.M., 2009. Van ili Caldıran ilçesi meralarının botanik kompozisyonları ve ot verimleri üzerine bir araștırma. Türkiye VIII. Tarla Bitkileri Kongresi, 19-22 Ekim, Hatay, s. $737-$ 740.

Cerit, T., Altın, M., 1999. Tekirdağ yöresi doğal meralarının vejetasyon yapısı ile bazı ekolojik özellikleri. Türkiye III. Tarla Bitkileri Kongresi, Cilt: 3, 15-18 Kasim, Adana, s. 6-11.

Cornellius, RD., Alınoğlu, N., 1962. Vejetasyon ölçme metodları ve otlatma kapasitesinin tayini. Tarım Bakanlığı Mesleki Kitaplar Serisi D. 66, Ankara.

Çaçan, E., 2014. Bingöl ili Merkez ilçesi YelesenDikme köyleri meralarının farklı yöney ve yükseltilerindeki bitki tür ve kompozisyonları ile ot verim ve kalitelerinin belirlenmesi. Doktora tezi, Dicle Üniversitesi Fen Bilimleri Enstitüsü, Diyarbakır.

Çaçan, E., Başbağ, M., 2016. Bingöl ili Merkez ilçesi Yelesen-Dikme köylerinin farklı yöney ve yükseltilerde yer alan mera kesimlerinde botonik kompozisyon ve ot veriminin değişimi. Ege Üniversitesi Ziraat Fakültesi Dergisi, 53(1): 1-9.

Çınar, S., 2001. Adana İli Tufanbeyli İlçesi Hanyeri köyü merasında verim ve botanik kompozisyonun saptanması üzerine bir araştırma. Yüksek lisans tezi, Cukurova Üniversitesi Fen Bilimleri Enstitüsü, Adana.

Erkovan, H.İ., Güllap, M.K., Daşc1, M., Koç, A., 2009. Changes in leaf area index, forage quality and above-ground biomass in grazed and ungrazed rangelands of Eastern Anatolia Region. Tarım Bilimleri Dergisi, 15(3): 217-223.

Erkun, V., 1971. Hakkari ve Van İllerinde Mera Araştırmaları. Tarım Bakanlığı Ziraat İşleri Genel Müdürlüğü Yayınları, G: 13, Ankara.

Gökkuş, A., 1994. Türkiye'nin kaba yem üretiminde çayır-mera ve yem bitkilerinin yeri ve önemi. Atatürk Üniversitesi Ziraat Fakültesi Dergisi, 25: 250-261.

Gökkuş, A., Avcı, M., Aydın, A., Mermer, A., Ulutaş, Z., 1993. Yükseklik eğim ve yöneyin mera vejetasyonlarına etkileri. Tarım Orman Köyişleri Bakanlığ1 Doğu Anadolu Tarımsal Araştırma Enstitüsü Yayın No: 13.

Güllap, M.K., 2010. Kargapazarı Dağında (Erzurum) farklı otlatma sistemi uygulamalarının mera bitki örtüsüne etkisi. Doktora tezi, Atatürk Üniversitesi Fen Bilimleri Enstitüsü, Erzurum.

Koç, A., Gökkuş, A., 1994. Güzelyurt köyü (Erzurum) mera vejetasyonunun botanik kompozisyonu ve toprağı kaplama alanı ile bırakılacak en uygun anız yüksekliğinin belirlenmesi. Türk Tarım ve Ormancilık Dergisi, 18: 495-500.

Morrison, J.A., 2003. Hay and pasture management, chapter 8 . extension educator, crop systems rockford extension center. (http://iah.aces.uiuc.edu/pdf/ Agronomy HB/ 08chapter.pdf), (Erişim tarihi: 01.07.2017). 
Nadir, M., 2010. Tokat ili Yeşilyurt köyü doğal merasının botanik kompozisyon, kuru madde verimi ve kalitesinin belirlenmesi. Yüksek lisans tezi, Gaziosmanpaşa Üniversitesi Fen Bilimleri Enstitüsü, Tokat.

Seydoşoğlu, S., 2018. Bazı doğal mera alanlarının bitki örtüsü özellikleri, mera durumu ve sağllğının belirlenmesi. Turkish Journal of Forestry, 19(4): 368-373.

Seydoşoğlu, S., Çaçan, E., Sevilmiş, U., 2019. Determination of botanical composition, yield and pasture quality ratings of infertile pastures in Kozluk district of Batman province of Turkey. Fresenius Environmental Bulletin, 28(4A): 3388-3394.

Seydoşoğlu, S., Kökten, K., 2019. Batman mera vejetasyonlarının bazı özellikleri. Harran Tarım ve Gida Bilimleri Dergisi, 23(1): 60-68.

Seydoşoğlu, S., Kökten, K., Sevilmiş, U., 2018. Mardin il ve ilçelerine bağlı köy meralarının temel vejetasyon özellikleri. Türk Tarım ve Doğa Bilimleri Dergisi, 5(4): 406-413.

Şahinoğlu, O., 2010. Bafra ilçesi Koşu köyü merasında uygulanan farklı 1slah yöntemlerinin meranın ot verimi, yem kalitesi ve botanik kompozisyonu üzerine etkileri. Doktora tezi, Ondokuz Mayıs Üniversitesi Fen Bilimleri Enstitüsü, Samsun.

Şen, Ç., 2010. Kilis ilinin bazı köylerindeki meralarda vejetasyon yapısı üzerine bir araștırma. Yüksek lisans tezi, Çukurova Üniversitesi Fen Bilimleri Enstitüsü, Adana.

Taşdemir, V., 2015. Elazığ ili Karakoçan ilçesi Bahçecik köyü merasında verim ve botanik kompozisyonunun saptanması üzerine bir araştırma. Yüksek lisans tezi, Bingöl Üniversitesi Fen Bilimleri Enstitüsü, Bingöl.

Tosun, F., Altın, M., 1986. Çayır Mera Yayla Kültürü ve Bunlardan Faydalanma Yöntemleri. Ondokuz Mayıs
Üniversitesi, Yayın No: 9, Ondokuz Mayıs Üniversitesi Basımevi, Samsun.

Tükel, T., 1981. Ulukışla'da korunan tipik bir step dağ merası ile eş orta malı meraların bitki örtüsü ve verim güçlerinin saptanması üzerine araştırmalar. Doçentlik tezi (Basılmamış), Çukurova Üniversitesi Ziraat Fakültesi, Adana.

Tükel, T., Hatipoğlu, R., 1997. Çayır Mera Amenajmanı. Çukurova Üniversitesi Ziraat Fakültesi Ofset Atölyesi, Genel Yayın No: 191, Ders Kitapları Yayin No: A-59, Adana.

Türker, A.H., Tükel, T., 2006. Mersin-Tarsus Olukkoyak köyü Topakardıç mevkisinde 1997 yılından beri korunmuş ağaçlandırma sahasındaki otsu vejetasyonun özellikleri üzerine bir araştırma. Doğu Akdeniz Ormancıllk Araştırma Müdürlüğü Doğa Dergisi, 12: 1-39.

Uzun, F., 2010. Tarla Bitkilerinde Laboratuvar Analizleri. Ondokuz Mayıs Üniversitesi, Ziraat Fakültesi Ders Notu No: 1, Ondokuz May1s Üniversitesi Basımevi, Samsun.

Van Soest, P.J., 1963. The use of detergents in the analysis of fibre feeds. II. A rapid method for the determination of fibre and lignin. Journal of the Association of Official Analytical Chemists, 46: 829835.

Van Soest. P.J., Wine, R.H., 1967. The use of detergents in the analysis of fibrous feeds. IV. Determination of plant cell wall constituents. Journal of the Association of Official Analytical Chemists, 50: 5055.

Y1lmaz, T., 1977. Konya İli Sorun Alanlarında Oluşan Meraların Bitki Örtüsü Üzerinde Araştırmalar. Tarım Bakanlığı Toprak Su Genel Müdürlüğü, Konya Bölge Toprak Su Araştırma Enstitüsü Yayınları Genel Yayın No: 46, Raporlar Serisi, No: 32 , Konya. 